International Journal of Instruction e-ISSN: 1308-1470 • www.e-iji.net

Article submission code: 20191010072242

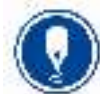

October $2020 \bullet$ Vol.13, No.4

p-ISSN: 1694-609X

pp. $47-64$

Received: 10/10/2019

Revision: 03/06/2020
Accepted: 23/06/2020

OnlineFirst:06/10/2020

\title{
Facebook Aided Lesson Study Design: Investigating Its Potentials on EFL Students' Literature Review Writing Skill
}

\author{
Susanto \\ IAIN Tulungagung, Indonesia, damarsusanto53@yahoo.co.id \\ Yudhi Arifani \\ Dr., Universitas Muhammadiyah Gresik, Indonesia, yudhi_arif@umg.ac.id \\ Farah Natchiar Mohd. Khaja \\ Ph.D., UPSI Malaysia, Malaysia, farach.natchiar@fbk.upsi.edu.my \\ Paulina \\ M.Pd., Universitas Muhammadiyah Gresik, Indonesia, paulina@umg.ac.id
}

\begin{abstract}
This study aimed to address three vital issues applying lesson study in EFL literature review writing course, namely to explain the effect of applying Facebook aided lesson study instruction model on the students' comprehension of literature review patterns/moves and literature review writing ability, to compare the effect of Facebook-aided lesson study and traditional teaching instruction model, and to elaborate the correlation between students' literature review patterns comprehension and their literature writing ability. Experimental research was employed to examine those three potentials. This research involved $30 \mathrm{EFL}$ learners, with 15 studying in a Facebook-aided lesson study instruction and 15 in a traditional classroom. Results indicated that the implementation of Facebook-aided lesson study in an EFL setting could not improve students' literature review comprehension, but this teaching approach could enhance students' literature writing ability. Finally, the positive correlation between EFL students' literature review comprehension and their literature writing ability was found from the study. Implementing a lesson study activities plan, do, and see using a Facebook-aided media in EFL teaching and learning context is recommended. This study could not comprehensively explore online teacher interactions during the Facebook discussion as it was more emphasized on outcome-based learning. Consequently, research on process-based interaction among lesson study teams is worth pursuing.
\end{abstract}

Keywords: Facebook, lesson study, learning potential, literature review, EFL

\section{INTRODUCTION}

This study aims to investigate the potentials of Facebook used in a lesson study activity to enhance EFL students' comprehension of literature review patterns and their ability to

Citation: Susanto, Arifani, Y., Khaja, F. N. M., \& Paulina. (2020). Facebook Aided Lesson Study Design: Investigating Its Potentials on EFL Students' Literature Review Writing Skill. International Journal of Instruction, 13(4), 47-64. https://doi.org/10.29333/iji.2021.1414a 
write a literature review as part of the thesis writing course. Several concerns underlie this inquiry. First, although the merits of social media such as Facebook have been found, there is still a general lack of study on how Facebook contributes to EFL teaching and learning (Aydin, 2014; Muls et al., 2019). Second, few studies has been found on the level of lesson study as one of teacher professional development media in EFL setting, while studies were found regarding both positive and negative effects of social media and lesson study (Janković, Nikolić, Vukonjanski, \& Terek, 2016; McCarthy, 2010; Michikyan, Subrahmanyam, \& Dennis, 2015; Patahuddin \& Logan, 2019; Robelia, Greenhow, \& Burton, 2011; Teclehaimanot \& Hickman, 2011). Third, there is a lack of research on the use of Facebook in a lesson study activity to enhance EFL students' literature review writing ability as part of research article writing. As the ability to write literature is one of the significant issues in conducting and reporting EFL research outcomes for a publication purpose, this study will provide practical and theoretical significance to the field of EFL teaching, learning, lesson study, and teacher professional development.

The development of social media based-technology changes the ways teachers and students interact and offer potentials to impact the quality of teaching and learning. Facebook is a registered trademark of Facebook Inc. According to Facebook (2018), it has massive users with approximately 1.49 billion users; the Facebook application also offers its users to create personal and group profiles, message, online chat, upload and download files, documents, and videos (Aydin, 2012). Further, the positive impact of Facebook in EFL teaching and learning has been found (Aydin, 2014; Muls et al., 2019). In a broad literature review on Facebook utilization within the EFL teaching and learning context, Aydin (2014) reports that the study has mainly discussed the level of interaction and communication between students and teachers involving the variables of gender, age, and year of the study. The result of the study reveals that EFL Turkish students remain passive in their interactions with their EFL teachers. He further asserts that male students are more active than those male students in their interaction with teachers. Moreover, in terms of age, the result does not show any significant correlation between age and the level of interactions. That is why in implementing a face-book lesson study in this current study, it is not necessary to classify the participant based on their gender and ages because previous findings revealed that there is no significant influence of face-book on age and gender.

In the field of pre-service teacher education programs, for example, Facebook has also been implemented to investigate the effect of using Facebook-based instruction on preservice teachers' learning and engagement (Saini \& Abraham, 2019). The results show that Facebook significantly improves their learning achievement and engagement. In addition, research on the benefits of lesson study conducted by several researchers like (Coşkun, 2017; Ducrey Monnier \& Gruson, 2018; Karabuğa \& Ilin, 2019; Lander, 2015; Mayrhofer, 2019) mostly implement lesson study using conventional version where they have to regularly meet and discuss face to face in implementing the three cycles of plan, do and see during lesson study activities. These studies also noticed that the implementation of lesson study does not use social media. That is why Facebook is offered with lesson study as a novelty of this study. 
The above previous studies indicate that Facebook has been widely probed in the area of teaching and learning with the purpose to enhance the quality of teaching and learning, but it is not implemented yet in the lesson study activity which aims to improve the quality of teaching through online collaboration model using Facebook. In this context, the use of Facebook as a lesson study media to promote its potential in EFL teaching and learning has not been studied yet.

\section{LITERATURE REVIEW}

\section{Facebook and Lesson Study: Theory Underpinning}

The following literature review discusses three main variables. The first theoretical framework underlies the implementation of Facebook in teacher professional development. Second, the underlying theory of the lesson study is also reviewed. Third, research on Facebook usage in the pedagogical area, and lesson study practices as part of teacher professional development are consecutively discussed. Finally, differences between previous studies and this current research are also offered as novelty and contributions to the body of knowledge.

First, this part elaborates on the theoretical perspective of Facebook usage. Facebook, a social networking site that allows the users to share, collaborate, and form social connections, has revolutionized the way individuals used to communicate and Interact (Saini \& Abraham, 2019). The implementation of social media such as Facebook in teaching and learning is rooted in social interaction and learning knowledge proposed by Vygotsky (1980). The notions of social interaction and learning theory claim that social network and interaction influence learners' cognitive and knowledge growth through interaction with more knowledgeable people (Vygotsky, 1980) and it is not just from the classroom environment, but it also comes from sociocultural events both traditionally or through social media such as using Facebook groups. This theory is now applied in the domain of teacher professional development where novice teachers enhance their professionals, knowledge through interaction with more experienced teachers through social media. Recently, these concepts are also applied for the sake of teacher professional development.

The term collaborative learning is more familiar than the word social interaction. It occurs as within the concept of collaborative learning are more reciprocal than of social interaction itself. In the context of teacher professional development such as lesson study where the objective is to enhance the quality of learning and teachers themselves, a collaborative professional learning offers opportunities for teachers to interact with other 'experienced' teachers and talk about specific pedagogical topics with regards to foster the quality of teaching and learning (Wilson \& Berne, 1999). This collaborative principle becomes the theoretical perspective of online professional development (Spicer \& Dede, 2006). From the merits of Facebook, as mentioned earlier, it can be utilized as a tool for professional collaboration development (Aydin, 2014; Muls et al., 2019). Therefore, this study attempts to blend between Face-book application and a lesson study activities as one of teaching professional development media to enhance the quality of teachers and students' learning qualities. 
Second, the following explanation reviews the theoretical perspective of the lesson study. Lesson study is one of collaborative teacher professional development activities conducted within the context of a classroom and school-based model. Under the umbrella of 'lesson study,' teacher collaboratively works together to design a lesson plan, implement classroom teaching activities, and reflect their teaching. This approach is generated from teaching-learning communities (TLCs) or collaborative teacher learning theory proposed by Grossman, Wineburg, and Woolworth (2001) and Stoll, Bolam, McMahon, Wallace, and Thomas (2006). They propose five essential themes under the implementation of teaching-learning communities, namely interaction and engagement, interdependence, shared interest and beliefs, a concern of individual views, and meaningful interactions. Those five essential elements are applied in this study. They are implemented as the theoretical frameworks in applying collaborative teaching using face-book media.

Third, research utilizing Facebook in teaching, learning, and professional development has been widely investigated (Yang, Wang, Woo, \& Quek, 2011). Different areas of research have also been scrutinized utilizing Facebook in EFL/ESL teaching and learning such as local and global collaboration of teachers for their professional development (Boyd \& Ellison, 2007; Muls et al., 2019; Spicer \& Dede, 2006), peer interaction (Wilson \& Berne, 1999), support learning (Manca \& Ranieri, 2016), course engagement and satisfaction (Thai, Sheeran, \& Cummings, 2019), literacy skill (Stewart, 2008), affective factors such as learners' interaction, motivation, classroom climate, and learners/faculty relationship, (Aydin, 2014; Li \& Pitts, 2009; Mazer, Murphy, \& Simonds, 2007; Steinfield, Ellison, \& Lampe, 2008). Those previous studies have been significantly contributed toward the body of knowledge of lesson study and teacher professional development. Even Facebook has also been implemented as media of teacher professional development, but so far, researchers have been implemented lesson study in a traditional model. Therefore, this study attempts to integrate Facebook within a lesson study approach to enrich the practical and theoretical perspective of lesson study within the digital era using Facebook.

\section{Research in Literature Review Writing}

A literature review is a vital part of writing a research proposal (Hsiao, 2015). It is one of the very exhausting parts in producing qualified research proposal because it involves so many complicated elements and skills as requirements to be able to write literature review adequately (Boote \& Beile, 2005; Randolph, 2009; Sayer, 2018). Even, Gall, Borg, and Gall (1996) estimate that doctoral students commonly accomplish their dissertation literature review between three to six months of effort. The complexities of writing literature are reflected in its moves (Fryer, 2012; Swales \& Feak, 2004), or genre/distinctive patterns (Richards \& Schmidt, 2013). There are four seminal works of patterns or moves of a research paper starting from introduction to literature review patterns proposed by numerous researchers (Fryer, 2012; Swales \& Feak, 2004). Swales and Feak (2004) propose the three main moves within creating a research space (CARS) model, namely establishing a territory, establishing, and occupying the niche. Next, Kwan (2006) introduces five categorizations of moves, namely counterclaiming, gapindicating, asserting, confirmative claims, asserting the relevancy claims, and abstracting 
or synthesizing the theoretical framework. Third, Lim (2012) lists indicating gap, stressing insufficient research, revealing the limitation of previous studies, contrasting previous findings, and adding novelty. Meanwhile, (Fryer, 2012) classifies literature moves into three points where each point has its sub-moves, namely presentation of the study background, gap identification, and statement of research purpose. The writer includes the patterns or moves of introduction section because in order to evaluate the quality of literature review it is necessary to understand the quality of the introduction itself. Further, understanding the quality of introduction lead to understanding the moves quality of the literature review section. Also, the patterns or moves of literature review applied in this study are based on adopted from Swales and Feak (2004), Kwan (2006), and Buela and Joseph (2015) for the literature review scale.

Many researchers have already addressed the issues of a literature review from different perspectives. First, Chen and Li (2019), for example, they examine how Chinese students establish their niche in literature review (LR) section of their thesis using a diachronic perspective majoring in MA linguistics and applied linguistics program. They addressed three central issues, namely comparing MA students' LR ability from two different period 1999-2000 and 2005-205, comparing strategies in writing their LR from those two different periods, and polarities performance in their works. The findings reveal that MA students' literature review moves have some differences in terms of frequency, strategy and evaluative polarity between the two periods because of different prior pieces of training. Besides, some students benefit substantially from their academic writing course taught by a writing expert.

Next, Rukmini (2019) investigated the structural development literature review from doctoral students in the English Education department. She employs Boote and Beile's (2005) literature review rubric to assess five doctoral students' literature review from their dissertation. This rubric lists five elements, namely, coverage, synthesis, methodology, significance, and rhetoric. The findings show that all five literature reviews from their dissertation have incomplete structural development. Further, their literature review scores also have unsatisfactory quality reflected from the rubric.

Moreover, Tseng (2018) analyzed 20 theoretical frameworks from researcher articles indexed in the Web of Science (SSCI) related to applied and social aspects of linguistics. Three essential findings are initiated. They are, most articles concern the explanation and elaboration of adopted theory, the proposed model does not aim to challenge, but to provide an alternative, writers put their theoretical frameworks in the introduction section to make it more concreted and developed or the justification of the study.

Those above previous studies have been successfully addressed the quality of literature review patterns from different settings and perspectives. They also illustrate the importance of understanding of literature review pattern for research class. However, few studies have examine how to teach an effective lesson study activities using a facebook media for the undergraduate students.

Although its importance of literature review in a research has been adequately addressed, students' ability in writing literature review has also been described 
comprehensively, moves elements of literature review are unveiled, literature review rubrics have also been issued by many researchers but they still fail to find an effective strategy on how to teach excellent literature review for the students. Therefore, this study attempts to find an effective strategy in teaching literature review in an EFL setting.

\section{Research Questions}

The primary aim of this paper is to find the potentials of Facebook-aided lesson study in the EFL teaching context. Therefore the following research questions are proposed:

1. Does Facebook aided lesson study instruction offer a significant effect on the students' comprehension of literature review patterns?

2. Is there any difference in the students' learning outcomes (their literature writing ability) between the EFL students who are taught using Facebook-aided lesson study and traditional teaching instruction model?

3. Do students' comprehension of literature review patterns correlate to their literature review writing ability?

\section{METHOD}

\section{Design}

This research belonged to experimental design. It aimed to examine how Facebookaided lesson instruction could affect EFL learners' comprehension in four aspects of the literature review and how this comprehension, in turn, could affect their literature review writing ability. The experimental group received a literature review instruction under a Facebook-aided lesson study approach while the control group continued their regular literature review classroom instruction without intervention.

\section{Participants}

The participants were 30 EFL undergraduate students ( 8 male and 22 female) majoring in English language education department from a private university in Indonesia. They were classified into experimental and control groups by using a World English Placement Test, adapted from Chase (2011). This test was administered to classify the students based on their English level. So that, an equal class was obtained. Reliability of the test was reported between .84 to .96 . In the experimental cohort, 15 EFL students were targeted, while the remaining 15 students were involved in the control group. The two groups of students were enrolled in the thesis writing class in the seventh semester of the academic year 2018. Since thesis writing is a compulsory subject under the English language Education curriculum, which helps facilitate them to write a research proposal and research report from their research, the students enrolled in the literature review writing course were selected to participate in the current study. This would not only help them comprehend the anatomy of literature review but specifically advance their ability in writing a literature review section

\section{Research Procedure}

This present study was designed based on five main principles of lesson study instruction (proposed by (Stoll et al., 2006). Those five principles were shared value \& vision, collective responsibility, reflective inquiry, collaboration, and collaborative 
learning. Both experimental and control groups were exploited over a period of six weeks. In the experimental group, there were three significant steps. Plan stage (before class), the researcher and two other thesis writing lecturers were engaged in a Facebook group discussion named as Facebook-aided Lesson Study (FB) group. It was created one week before the project was implemented. Through online media, we discussed the lesson plan, prepared learning activities, research articles from reputable journals, comprehension, and literature writing tasks for the whole six meetings. Do stage (whilstteaching practice), the researcher, as a model lecturer, implemented classroom teaching and learning for the whole meetings. The other two writing lecturers took their role as indirect observers. They had to observe the recorded teaching videos, which were uploaded into a Facebook-aided lesson study group. The focus of observations rested mainly on students' learning activities. They had to carefully examine how the students were learning during classroom teaching practice from the videos. See/reflection stage (after teaching practice), and the lecturer model made a recoded video after he finished teaching. This video contained self-teaching reflection reporting how he had made the students learning through the previously prepared teaching activities from the lesson plan. What made the students learned and what made the students did not learn during classroom teaching sessions were reported in the videos. Both recorded video (teaching and reflection videos) were uploaded into the Facebook-aided lesson study group. Through this online media, the researcher and other two writing lecturers discussed carefully to address students' learning issues resulted from the teaching practices. All discussion chats, uploaded documents, videos, comments, photos were achieved in the FB groups. All notes were used to improve students' literature review learning in each teaching session. Those three primary cycles were rotated for six weeks, where every week filled up with a plan, do, and see cycles using the FB group.

Meanwhile, for the traditional lesson study class, the writer did similar activities to the experimental group did but there was no reflective teaching and lesson study were applied. Lesson plan design, teaching material design, task design, and assessment were prepared and implemented individually. Teaching activities was also the same contents such as comprehending scholarly article from reputable journals, giving guided questions to comprehend literature review moves or patterns, than practice developing a good literature review, discussing the result to the rubric of literature review scale.

\section{Data Collection}

This experimental study tested the differences of students' scores between the two cohorts were exposed to dissimilar conducts (Facebook aided lesson study versus conventional teaching instruction) as mirrored in the dependent variable (i.e., students' literature review tests attained from pretest and posttest, students' worksheet progresses from the first up to the six projects. Meanwhile, the independent variable was classroom instruction types, namely teaching literature review for the seventh-semester students in a thesis writing course using Facebook-aided lesson study and conventional lesson study instruction models. Two different tests were employed during the study. First, a subjective comprehension test covering 10 item questions using a short answer format was administered to assess students' understanding of the patterns of a literature review 
from six reputable journal articles (Scopus indexed article from Q1). Secondly, a literature review writing test was adapted from Swales and Feak (2004), and Kwan (2006) were also applied to assess students' ability in writing literature review section from opening, body, and closing paragraph. Those two different tests were consecutively administered for both pretest and posttests. A literature review rubric adopted from Buela and Joseph (2015) was also implemented to score their ability in writing a literature review section.

In this case, the students' literature writing compositions were assessed and scored by two different senior writing lecturers (all are Ph.D.) who teach writing and are expert in international scholarly publications. When they scoring result were different, the average mean scores from those two lecturers were used to justify students' writing literature review ability.

Meanwhile, the detail of teaching practices between the two different groups was presented in the following figure.

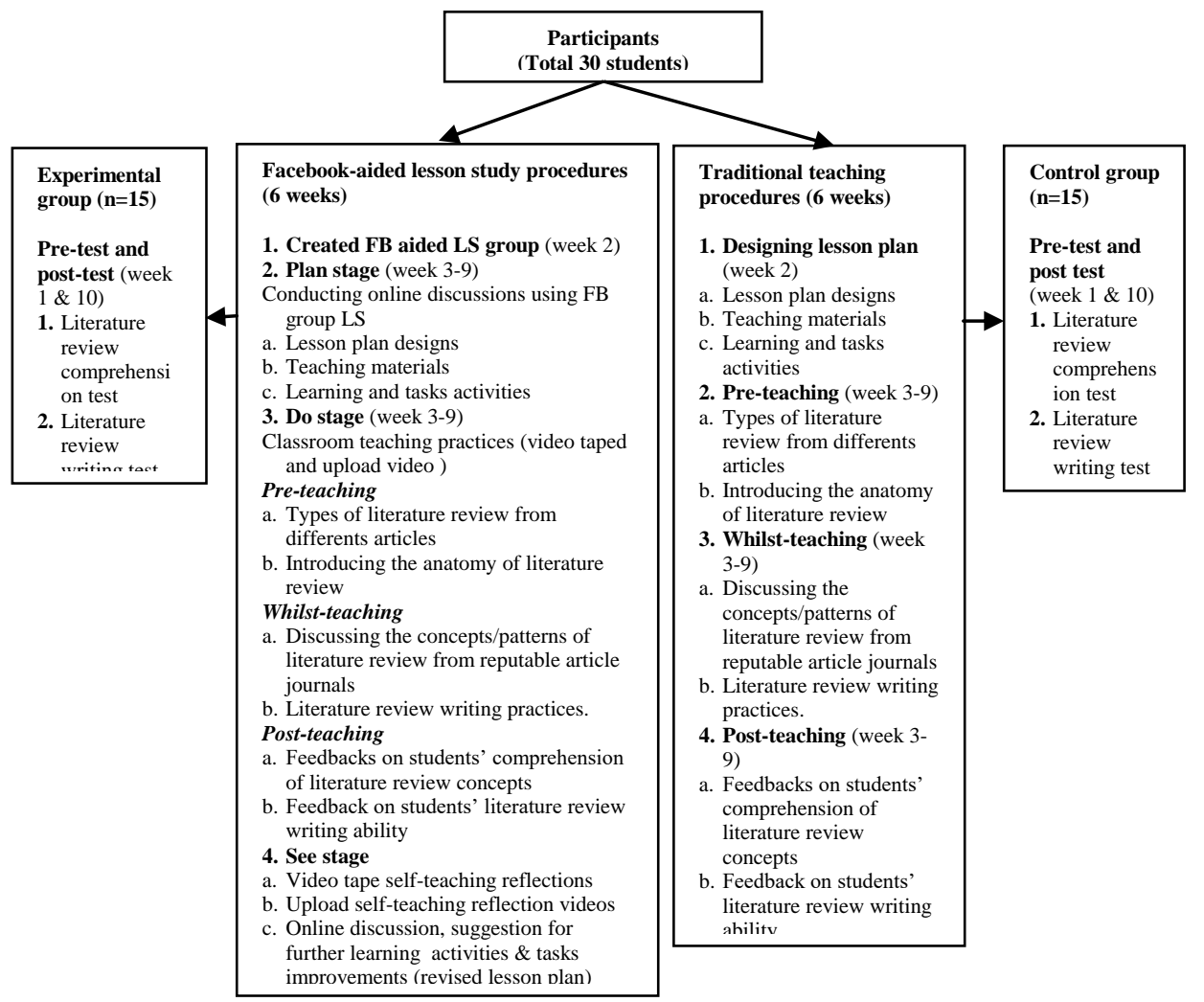

Figure 1

Research Design Summary 


\section{Data analysis}

In terms of statistical analysis, two different types of statistical tests were employed. First, a t-test was conducted to examine whether there was a significant difference in scores or not between the EFL students' comprehension of literature review patterns and their literature review writing ability taught using Facebook-aided lesson study in the experimental group (Research Question or RQ1). Next, statistical analysis using one way ANOVA was applied to examine whether there was a significant difference in scores or not between the two different groups (RQ2). In the experimental group, the students were taught using Facebook-aided lesson study instruction model and the control group; the students were taught using traditional teaching instruction. Then, to explain whether there was a positive correlation or nor between students' comprehension of literature review patterns and their ability in writing a literature review section (RQ3).

\section{FINDINGS}

The results of normality and homogeneity tests from the experimental and control groups were statistically presented in the table below.

Table 1

Normality Test using One-Sample Kolmogorov-Smirnov

\begin{tabular}{|c|c|c|c|c|c|}
\hline & & $\begin{array}{l}\text { Face book-Aided } \\
\text { LS Class } \\
\text { (Literature } \\
\text { Review } \\
\text { Comprehension) }\end{array}$ & $\begin{array}{l}\text { Face book- } \\
\text { Aided LS Class } \\
\text { (Literature } \\
\text { Review Writing } \\
\text { Ability) }\end{array}$ & $\begin{array}{l}\text { Traditional } \\
\text { Teaching Class } \\
\text { (Literature } \\
\text { Review } \\
\text { Comprehension) }\end{array}$ & $\begin{array}{l}\text { Traditional } \\
\text { Teaching Class } \\
\text { (Literature } \\
\text { Review Writing } \\
\text { Ability) }\end{array}$ \\
\hline $\mathrm{N}$ & & 15 & 15 & 15 & 15 \\
\hline Normal & Mean & 75.2000 & 77.4667 & 69.6667 & 72.6000 \\
\hline Parameters ${ }^{\mathrm{a}, \mathrm{b}}$ & $\begin{array}{l}\text { Std. } \\
\text { Deviation }\end{array}$ & 3.48876 & 3.31375 & 3.45722 & 3.56170 \\
\hline Most Extreme & Absolute & .191 & .196 & .157 & .177 \\
\hline Differences & $\begin{array}{l}\text { Positive } \\
\text { Negative }\end{array}$ & $\begin{array}{l}.144 \\
-.191\end{array}$ & $\begin{array}{l}.188 \\
-.196\end{array}$ & $\begin{array}{l}.128 \\
-.157\end{array}$ & $\begin{array}{l}.177 \\
-.150\end{array}$ \\
\hline $\begin{array}{l}\text { Test Statistic } \\
\text { Asymp. Sig. (2-tailed) }\end{array}$ & & $\begin{array}{l}.191 \\
.147^{c}\end{array}$ & $\begin{array}{l}.196 \\
.127^{\mathrm{c}}\end{array}$ & $\begin{array}{l}.157 \\
.200^{\mathrm{c}, \mathrm{d}}\end{array}$ & $\begin{array}{l}.177 \\
.200^{\mathrm{c}, \mathrm{d}}\end{array}$ \\
\hline
\end{tabular}

Table 1 illustrates that the normality value from both groups. The results of normality tests were beyond alpha 5\% with $p=.147$ and .127 in terms of students' literature review comprehension and their literature writing ability in the experimental group. Meanwhile, the normality scores for the traditional group in terms of students' comprehension and literature writing ability were simultaneously $p=2.00$. These index scores indicated that the data obtained from the two groups were normally distributed. It means the students' comprehension scores were normally distributed. Therefore, there was no extreme scores performance in this case.

Table 2

Test of Homogeneity of Variances

\begin{tabular}{llll}
\hline Score & & \\
\hline Levene Statistic & df1 & df2 & Sig. \\
\hline .360 & 3 & 56 & .782 \\
\hline
\end{tabular}

Sig > 0.05 
Table 2 describes the results of homogeneity of the two groups (Facebook-aided LS teaching model and traditional teaching model) using the Levene's statistical analysis. The index showed the result of the test was $p=.782$ higher than the $p$-value (sig.) $p=.05$. Since the results of the $p$-value were higher than the alpha's $(5 \%)$, the calculated data were homogeneous. It means that the students' comprehension scores among the population indicated similar characteristics in terms of comprehension abilities.

Research question 1. Does Facebook aided lesson study instruction offer a significant effect on the students' comprehension of literature review patterns?

To answer this research question, post-test mean scores comparison of the two groups and an independent t-test were employed to explain whether there was a significant difference in literature review comprehension scores or not between students who were taught using Facebook-aided lesson study and those students who were taught using traditional teaching model. The two different analysis models are presented in the following table.

Table 3

Post-Test mean Score Comparisons of EFL Students' Literature Review Comprehension

\begin{tabular}{clcccc}
\hline & Treatment & N & Mean & $\begin{array}{l}\text { Std. } \\
\text { Deviation }\end{array}$ & $\begin{array}{l}\text { Std. Error } \\
\text { Mean }\end{array}$ \\
\hline \multirow{2}{*}{ Score } & $\begin{array}{l}\text { Traditional Teaching } \\
\text { Class (Literature Review }\end{array}$ & 15 & 72.6000 & 3.56170 & .91963 \\
$\begin{array}{l}\text { Comprehension) } \\
\text { Face book-Aided LS } \\
\text { Class (Literature Review } \\
\text { Comprehension) }\end{array}$ & 15 & 75.2000 & 3.48876 & .90079 \\
\hline
\end{tabular}

Table 3 portrays the mean score of learners' literature review patterns comprehension who were taught using Face book-aided lesson study and traditional teaching class. From the above table, the mean score of the two groups' slightly yielded different score gain. The students' literature review comprehension average score in the experimental group was 75 higher than those in the control group 72.

Table 4

Independent T-Test Results of EFL Students' Literature Review Comprehension

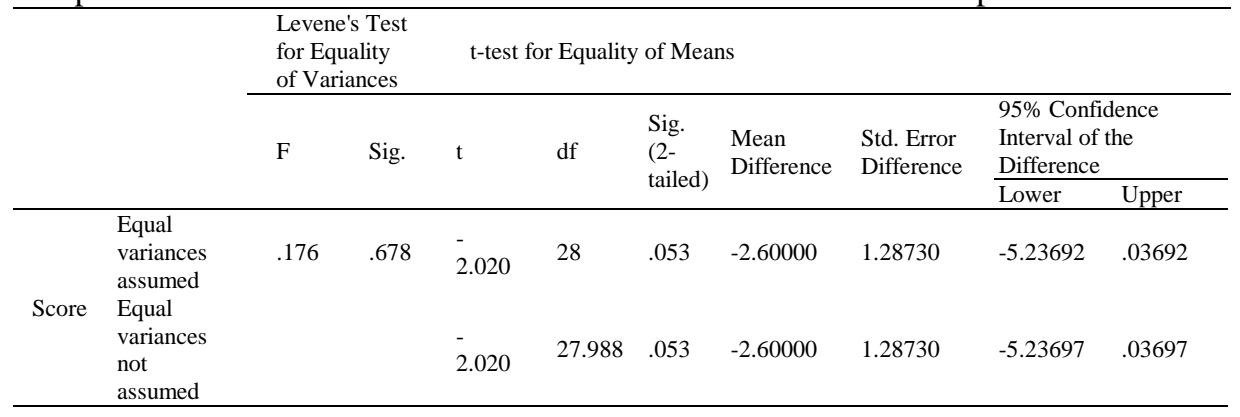


Table 4 illustrates the results of independent t-test to explain whether there was a significant difference in students' literature review comprehension scores between the two different cohorts. From the table, it could be seen that the significance level (sig. 2 tailed) was $.53>.005$. Therefore, it was convinced that Ho was not accepted. It could also be explained that there was no significant difference in EFL students' literature review comprehension scores between the students who were taught using Facebookaided LS and those students who were taught using traditional ones.

Research question 2. Is there any difference in the students' learning outcomes (their literature writing ability) between the EFL students who are taught using Facebookaided lesson study and traditional teaching instruction model?

To answer this research question, mean scores comparison of the two groups and an independent t-test were also employed to explain whether there was a significant difference of EFL students' literature review writing scores or not between students who were taught using Facebook-aided lesson study and those students who were taught using traditional teaching instruction. The two different analysis models are presented in the table below.

Table 5

Post-Test mean Score Comparison of Students' Literature Review Writing Ability

\begin{tabular}{|c|c|c|c|c|c|}
\hline & Treatment & $\mathrm{N}$ & Mean & $\begin{array}{l}\text { Std. } \\
\text { Deviation }\end{array}$ & $\begin{array}{l}\text { Std. Error } \\
\text { Mean }\end{array}$ \\
\hline \multirow{2}{*}{ Score } & $\begin{array}{l}\text { Traditional Teaching Class } \\
\text { (Literature Review Writing } \\
\text { Ability) }\end{array}$ & 15 & 69.6667 & 3.45722 & .89265 \\
\hline & $\begin{array}{l}\text { Face book-Aided LS Class } \\
\text { (Literature Review Writing } \\
\text { Ability) }\end{array}$ & 15 & 77.4667 & 3.31375 & .85561 \\
\hline
\end{tabular}

Table 5 illustrates the mean score of learners' literature review writing score differences between EFL students who were taught using Facebook-aided lesson study and traditional teaching approach. From the above table, the mean score of the two groups significantly performed different mean gain. The students' literature review writing's average score in the experimental group was 77.4667 higher than those in the control group 69.6667.

Table 6

Independent T-Test Results of EFL Students' Literature Review Writing Ability

\begin{tabular}{|c|c|c|c|c|c|c|c|c|c|c|}
\hline & & $\begin{array}{l}\text { Leve } \\
\text { Equa } \\
\text { Varia }\end{array}$ & $\begin{array}{l}\text { s Test } \\
\text { of } \\
\text { es }\end{array}$ & t-test $f$ & Equalit & of Means & & & & \\
\hline & & F & Sig. & $\mathrm{t}$ & df & $\begin{array}{l}\text { Sig. (2- } \\
\text { tailed) }\end{array}$ & $\begin{array}{l}\text { Mean } \\
\text { Difference }\end{array}$ & $\begin{array}{l}\text { Std. Error } \\
\text { Difference }\end{array}$ & $\begin{array}{l}95 \% \text { Confi } \\
\text { Interval of } \\
\text { Difference }\end{array}$ & $\begin{array}{l}\text { dence } \\
\text { the }\end{array}$ \\
\hline & & & & & & & & & Lower & Upper \\
\hline & $\begin{array}{l}\text { Equal } \\
\text { variances } \\
\text { assumed }\end{array}$ & .097 & .757 & $-\overline{6}-308$ & 28 & .000 & $\overline{7} .80000$ & 1.23648 & -10.33282 & -5.26718 \\
\hline Score & $\begin{array}{l}\text { Equal } \\
\text { variances not } \\
\text { assumed }\end{array}$ & & & $\begin{array}{l}- \\
6.308\end{array}$ & 27.950 & .000 & $\overline{7.80000}$ & 1.23648 & -10.33302 & -5.26698 \\
\hline
\end{tabular}


Table 6 illustrates the results of independent t-test to explain whether there was a significant difference in students' literature review writing scores between the two different combinations. From the above table, it could be seen that the significance level (sig. 2 tailed) was $.000<.005$. Therefore, it was convinced that Ho was accepted. It could also be explained that there were significant differences in EFL students' literature review writing scores between the students who were taught using Facebook-aided LS and those students who were taught using the traditional teaching approach.

Research question 3. Do students' comprehension of literature review patterns correlate to their literature review writing ability?

A correlational analysis was employed to examine whether there was a positive or negative correlation between EFL students' literature review comprehension and their literature review writing ability.

Table 7

Correlation Test Model from the Two Groups

\begin{tabular}{|c|c|c|c|c|c|c|c|c|c|}
\hline \multirow[b]{2}{*}{ Model } & \multirow[b]{2}{*}{$\mathrm{R}$} & \multirow[b]{2}{*}{$\begin{array}{l}\mathrm{R} \\
\text { Square }\end{array}$} & \multirow[b]{2}{*}{$\begin{array}{l}\text { Adjusted } \\
\mathrm{R} \\
\text { Square }\end{array}$} & \multirow[b]{2}{*}{$\begin{array}{l}\text { Std. Error } \\
\text { of the } \\
\text { Estimate }\end{array}$} & \multicolumn{5}{|c|}{ Change Statistics } \\
\hline & & & & & $\begin{array}{l}\mathrm{R} \\
\text { Square } \\
\text { Change }\end{array}$ & $\begin{array}{l}\mathrm{F} \\
\text { Change }\end{array}$ & $\begin{array}{l}\mathrm{df} \\
1\end{array}$ & $\mathrm{df} 2$ & $\begin{array}{l}\text { Sig. F } \\
\text { Change }\end{array}$ \\
\hline 1 & $.875^{\mathrm{a}}$ & .765 & .747 & 1.75358 & .765 & 42.414 & 1 & 13 & .000 \\
\hline
\end{tabular}

Table 7 explains the correlation results from the two groups. The result of post test scores of the two groups were statistically analyzed. This table indicates that there was a positive correlation between EFL students' literature comprehension ability and their literature review writing ability because the $\mathrm{R}$ square change value was .765 , and it was closer to 1 as a positive correlation indicator. Consequently, it could also be asserted that when the students' literature review comprehension score is high, their literature review writing score also high.

\section{DISCUSSION}

This research aimed to address three potential issues. First, it aimed to find whether Facebook aided lesson study instruction has a significant effect on the students' comprehension of literature review patterns. Second, it aimed to find whether Facebook aided lesson study instruction has a significant effect on the students' literature review writing. Third, it also aimed to examine whether there was a positive correlation between students' literature review comprehension and their literature writing ability. The main discussions were adequately addressed under the three findings for this study.

The first findings revealed that there was no significant difference in EFL students' literature review comprehension scores between the students who were taught using Facebook-aided LS and those students who were taught using traditional ones. In this session, all students were assigned to answer a comprehension question. The questions were derived from a research article indexed both in SSCI and Scopus Q1. The literature review section of the article was printed out. The questions covered three main areas, namely the introduction section, body, and closing paragraph. The three main areas were interpreted into questions covering how the author started writing the introductory 
paragraph of the literature review section, how main variable of the research was defined, how the underlying theory was presented, how many previous studies were overviewed, what the differences of the previous studies and currents studies were, how many previous studies are elaborated, and how novelty is written in this section. In this session, Facebook-aided LS using a Facebook group they discussed through their FB account to prepare learning activities so that through the prepared learning activities, the students could autonomously find the correct answer to the questions. Meanwhile, for the control group, the teacher individually prepared lesson design with similar learning activities. Although they were treated differently, their literature comprehension remained the same. This probably occurs because EFL students' literature review comprehension is not influenced by both individual and collaborative teaching as well, but their academic vocabulary mastery plays crucial roles in answering the comprehension question on literature review patterns. The difficulty level of the literature review texts could not be decoded with lesson study and individual teaching strategies but through academic vocabulary. This is probably true as (Lawrence, Hagen, Hwang, Lin, \& Lervåg, 2019) and Cain and Oakhill (2014) asserted that vocabulary plays an important role in supporting learners' comprehension.

The second results showed that EFL students' literature writing abilities who were taught using the Facebook-aided lesson study approach were higher than those students who were taught using traditional ones. This finding was similar to previous studies implemented lesson study model in their teaching and learning (Aydin, 2014; Li \& Pitts, 2009; Mazer, Murphy, \& Simonds, 2007; Steinfield, Ellison, \& Lampe, 2008). All these previous findings asserted that lesson study could be very beneficial in EFL teaching and learning. In the context of Facebook-aided lesson study, the students' writing progress was carefully assessed collaboratively by the three writing teachers through the teachers' Facebook LS group. In this point, during whilst-teaching practice, a videotaped was utilized to record students' learning activities. Then, the model teacher made a selfreflection video. Both videos were then uploaded into teachers' Facebook LS groups. Comments and suggestions towards the running of writing activity and forthcoming learning activities were regularly improved. Two essential points from this implementation were generated. First, the teacher model's self-reflection video benefits other writing teachers to improve the quality of learning as well as the quality of students' writing. Second, collaborative teaching also benefitted enhances students' learning in comprehending both literature review patterns from the articles and writing practices.

The third results indicated that there was a positive correlation between EFL students' literature review comprehension and their literature writing abilities. The students who had higher scores of their literature comprehension would also have higher scores in their literature review writing. Conversely, the students who got lower scores into their literature comprehension would also get lower scores in their literature review writing. These findings positively corresponded with the previous results asserted by Phillips Galloway and Uccelli (2019). They echoed that reading comprehension and summary tests (in this case, it belonged to literature review comprehension from a journal article) and writing tasks from the same academic source texts (in this study, it belonged to 
literature review text from journal article as well) had a positive correlation with EFL students' writing ability.

\section{CONCLUSION AND RECOMMENDATION}

This research investigated to compare whether EFL learners taught using the Facebookaided lesson study approach performed better or not in their literature review comprehension and their literature review writing abilities. Next, it also aimed to see whether there was a positive correlation between EFL students' literature review comprehension and their literature review writing scores. Overall, the results revealed that students who were taught using the Facebook-aided lesson study approach performed better in their literature writing ability, but their literature review comprehension scores remained the same. The findings also demonstrated that EFL students' literature comprehension scores positively correlated with their literature writing scores.

It is recommended for EFL teachers and departments to integrate a lesson study program into EFL curriculum and EFL teaching-learning practices for classroom-based teacher professional development and teaching quality improvement. During the implementation of the lesson study, it is suggested for EFL teachers to use Facebook media during the plan, do, and see cycles. As the research sample was relatively very small, it is suggested for further researchers to replicate the study using a larger sample. This study emphasized on the EFL learners' learning outcomes rather than on its processed-based as the online interactions using Facebook among the lesson study teams could not be portrayed comprehensively, it is recommended for further researchers to scrutinize its online interaction process during Facebook interactions. This study could not comprehensively explore online teacher interactions during the Facebook discussion as it was more emphasized on outcome-based learning. Consequently, research on processbased interaction among lesson study teams is worth pursuing

\section{ACKNOWLEDGEMENTS}

This research is part of Penugasan Dosen di Sekolah (University Lecturer Teaches at School Grant) from Ministry of Research and Technology Directorate of High Education 2019.

\section{REFERENCES}

Aydin, S. (2012). A review of research on Facebook as an educational environment. Educational Technology Research and Development, 60(6), 1093-1106.

Aydin, S. (2014). Foreign language learners' interactions with their teachers on Facebook. System, 42, 155-163.

Boote, D. N., \& Beile, P. (2005). Scholars before researchers: On the centrality of the dissertation literature review in research preparation. Edu. Researcher, 34(6), 3-15.

Boyd, D. M., \& Ellison, N. B. (2007). Social network sites: Definition, history, and scholarship. Journal of Computer-Mediated Communication, 13(1), 210-230. 
Buela, S., \& Joseph, M. C. (2015). Relationship between Personality and Teacher Effectiveness of High School Teachers. The International Journal of Indian Psychology, 3.

Cain, K., \& Oakhill, J. (2014). Reading comprehension and vocabulary: Is vocabulary more important for some aspects of comprehension? LAnnee Psychologique, 114(4), 647-662.

Chase, R.T. (2011). World English placement test package. Retrieved from http://cengage.com.br/parcerias/goup/pdfs/World_English_Placement_Test_Package.pdf.

Chen, X., \& Li, M. (2019). Chinese learner writers' niche establishment in the literature review chapter of theses: A diachronic perspective. Journal of English for Academic Purposes, 39, 48-58. https://doi.org/10.1016/j.jeap.2019.03.006.

Coşkun, A. (2017). The application of lesson study in teaching English as a foreign language. İn̈̈nü Üniversitesi Ĕ̆itim Fakültesi Dergisi, 18(1), 151-162.

Ducrey Monnier, M., \& Gruson, B. (2018). Lesson Study research and initial teacher education: how to teach interactive speaking in English as a Foreign Language (EFL) in primary school? RISTAL. Res. in Subject-Matter Teaching and Learning, 1, 119-134.

Facebook (2018). Statistics. Palo Alto, CA: Facebook.

Fryer, D. L. (2012). Analysis of the generic discourse features of the English-language medical research article: A systemic-functional approach. Functions of Language, 19(1), 5-37.

Gall, M. D., Borg, W. R., \& Gall, J. P. (1996). Educational research: An introduction. Longman Publishing.

Grossman, P., Wineburg, S., \& Woolworth, S. (2001). Toward a theory of teacher community. The Teachers College Record, 103, 942-1012.

Hsiao, C. (2015). Genre Analysis of Low-rated and High-rated Literature Reviews by EFL Postgraduates. International Journal of English Language Teaching, 3(1), 1.

Janković, B., Nikolić, M., Vukonjanski, J., \& Terek, E. (2016). The impact of Facebook and smartphone usage on the leisure activities and college adjustment of students in Serbia. Computers in Human Behavior, 55, 354-363.

Karabuğa, F., \& Ilin, G. (2019). Practicing lesson study in a Turkish education context: Considering the challenges, suggestions, and benefits from EFL teachers' perspectives. International Journal for Lesson and Learning Studies, 8(1), 60-78.

Kwan, B. S. (2006). The schematic structure of literature reviews in doctoral theses of applied linguistics. English for Specific Purposes, 25(1), 30-55.

Lander, B. (2015). Lesson study at the foreign language university level in Japan: Blended learning, raising awareness of technology in the classroom. International 
Journal for Lesson and Learning Studies, 4(4), 362-382.

Lawrence, J. F., Hagen, A. M., Hwang, J. K., Lin, G., \& Lervåg, A. (2019). Academic vocabulary and reading comprehension: exploring the relationships across measures of vocabulary knowledge. Reading and Writing, 32(2), 285-306.

Li, L., \& Pitts, J. P. (2009). Does it really matter? Using virtual office hours to enhance student-faculty interaction. Journal of Information Systems Education, 20(2), 175.

Lim, J. M.-H. (2012). How do writers establish research niches? A genre-based investigation into management researchers' rhetorical steps and linguistic mechanisms. Journal of English for Academic Purposes, 11(3), 229-245.

Manca, S., \& Ranieri, M. (2016). Is Facebook still a suitable technology-enhanced learning environment? An updated critical review of the literature from 2012 to 2015. J. of Computer Assisted Learning, 32(6), 503-528. https://doi.org/10.1111/jcal.12154.

Mayrhofer, E. (2019). Lesson study and teachers' beliefs: How a Bourdieuian perspective could make a difference. International Journal for Lesson and Learning Studies, 8(1), 19-33. https://doi.org/10.1108/IJLLS-11-2018-0091.

Mazer, J. P., Murphy, R. E., \& Simonds, C. J. (2007). I'll see you on "Facebook": The effects of computer-mediated teacher self-disclosure on student motivation, affective learning, and classroom climate. Communication education, 56(1), 1-17.

McCarthy, J. (2010). Blended learning environments: Using social networking sites to enhance the first-year experience. Australasian J. of Educational Technology, 26(6).

Michikyan, M., Subrahmanyam, K., \& Dennis, J. (2015). Facebook use and academic performance among college students: A mixed-methods study with a multi-ethnic sample. Computers in Human Behavior, 45, 265-272.

Muls, J., Triquet, K., Vlieghe, J., De Backer, F., Zhu, C., \& Lombaerts, K. (2019). Facebook group dynamics: an ethnographic study of the teaching and learning potential for secondary school teachers. Learning, Media, and Technology, 44(2), 162-179. https://doi.org/10.1080/17439884.2019.1583670.

Patahuddin, S. M., \& Logan, T. (2019). Facebook as a mechanism for informal teacher professional learning in Indonesia. Teacher Development, 23(1), 101-120. https://doi.org/10.1080/13664530.2018.1524787.

Phillips Galloway, E., \& Uccelli, P. (2019). Beyond reading comprehension: exploring the additional contribution of core academic language skills to early adolescents' written summaries. Reading and Writing: An Interdisciplinary Journal, 32(3), 729-759.

Randolph, J. (2009). A guide to writing the dissertation literature review. A PeerReviewed Electronic Journal, 14(13), 1-13.

Richards, J. C., \& Schmidt, R. W. (2013). Longman dictionary of language teaching and applied linguistics: Routledge. 
Robelia, B. A., Greenhow, C., \& Burton, L. (2011). Environmental learning in online social networks: Adopting environmentally responsible behaviors. Environmental Education Research, 17(4), 553-575.

Rukmini, D. (2019). The literature review in the dissertation: The language education of Universitas Negeri Semarang. Paper presented at the UNNES International Conference on English Language Teaching, Literature, and Translation (ELTLT 2018).

Saini, C., \& Abraham, J. (2019). Implementing a Facebook-based instructional approach in pre-service teacher education: An empirical investigation. Computers \& Education, $128,243-255$.

Sayer, E. J. (2018). The anatomy of an excellent review paper. Functional Ecology, $32(10), 2278-2281$.

Spicer, D. E., \& Dede, C. (2006). Collaborative design of online professional development: Building the Milwaukee professional support portal. Journal of Technology and Teacher Education, 14(4), 679-699.

Steinfield, C., Ellison, N. B., \& Lampe, C. (2008). Social capital, self-esteem, and use of online social network sites: A longitudinal analysis. Journal of Applied Developmental Psychology, 29(6), 434-445.

Stewart, P. (2008). Facebook: a school librarian's tool for building a community of readers'. International Association of School Librarianship, 1-17.

Stoll, L., Bolam, R., McMahon, A., Wallace, M., \& Thomas, S. (2006). Professional learning communities: A review of the literature. J. of Edu. Change, 7(4), 221-258.

Swales, J. M., \& Feak, C. B. (2004). Academic writing for graduate students: Essential tasks and skills (Vol. 1): University of Michigan Press Ann Arbor, MI.

Teclehaimanot, B., \& Hickman, T. (2011). Student-teacher interaction on Facebook: What students find appropriate. TechTrends, 55(3), 19.

Thai, M., Sheeran, N., \& Cummings, D. J. (2019). We're all in this together: The impact of Facebook groups on social connectedness and other outcomes in higher education. The Internet and Higher Education, 40, 44-49.

Tseng, M.-Y. (2018). Creating a theoretical framework: On the move structure of theoretical framework sections in research articles related to language and linguistics. Journal of English for Academic Purposes, 33, 82-99.

Vygotsky, L. S. (1980). Mind in society: The development of higher psychological processes: Harvard University Press.

Wilson, S. M., \& Berne, J. (1999). Chapter 6: Teacher learning and the acquisition of professional knowledge: An examination of research on contemporary professional development. Review of Research in Education, 24(1), 173-209.

Yang, Y., Wang, Q., Woo, H. L., \& Quek, C. L. (2011). Using Facebook for teaching 
and learning: A review of the literature. International Journal of Continuing Engineering Education and Life-Long Learning, 21(1), 72-86. 